\title{
Activation of adenosine deaminase in MCF-7 cells through IGF-estrogen receptor $\alpha$ crosstalk
}

\section{W Xie, R Duan and S Safe}

Department of Veterinary Physiology \& Pharmacology, Texas A\&M University, 4466 TAMU,
College Station, Texas 77843-4466, USA

(Requests for offprints should be addressed to S H Safe; Email: ssafe@cvm.tamu.edu)

\begin{abstract}
Adenosine deaminase (ADA) regulates cellular levels of adenosine and deoxyadenosine, and $17 \beta$-estradiol $\left(\mathrm{E}_{2}\right)$ induces ADA mRNA in MCF7 human breast cancer cells. IGF-I also induces ADA gene expression in these cells, and induction of this response through IGF activation of estrogen receptor $\alpha(\mathrm{ER} \alpha)$ was further investigated. IGF and other polypeptide growth factors induce reporter gene expression in MCF-7 cells cotransfected with ER $\alpha$ expression plasmid and pADA211, a construct containing the -211 to +11 region of the ADA gene promoter which is required for high basal and $\mathrm{E}_{2}$-inducible activity. Deletion analysis of this
\end{abstract}

promoter demonstrates that IGF activates $\mathrm{ER} \alpha / \mathrm{Sp} 1$ interactions with multiple GC-rich sites in the promoter and this response is abrogated in cells transfected with $\mathrm{ER} \alpha$ containing mutations at $\operatorname{Ser}^{118}$ or $\operatorname{Ser}^{163}$. IGF induces both MAPK (mitogen-activated protein kinase) and PI3-K (phosphatidylinositol-3-kinase) phosphorylation cascades in MCF-7 cells; however, using a series of inhibitors and dominant negative constructs, our results show that induction of ADA by IGF activation of $\mathrm{ER} \alpha / \mathrm{Sp} 1$ is dependent on the MAPK signaling pathway.

Fournal of Molecular Endocrinology (2001) 26, 217-228

\section{INTRODUCTION}

$17 \beta$-Estradiol $\left(\mathrm{E}_{2}\right)$, insulin and growth factor polypeptides, such as insulin-like growth factor-I (IGF-I), transforming growth factor- $\alpha(\mathrm{TGF} \alpha)$ and epidermal growth factor (EGF), induce proliferation of estrogen receptor (ER)-positive breast cancer cell lines (Furlanetto \& DiCarlo 1984, Bates et al. 1988, Dickson \& Lippman 1988, 1991, 1995, Karey \& Sirbasku 1988, Wilding et al. 1988, Fernandez et al. 1994, Westley \& May 1994, Kato et al. 1998, Smith 1998, Weigel \& Zhang 1998). Growth factor and $\mathrm{E}_{2}$-induced growth of breast cancer cells is accompanied by an increase in the number of cells in $\mathrm{S}$ phase of the cell cycle and enhanced expression of some of the same genes including immediate-early genes such as c-fos, myc and early growth response-1 (egr-1), several genes involved in cell cycle progression, and other genes/gene promoter constructs that are $\mathrm{E}_{2}$ responsive (Furlanetto \& DiCarlo 1984, IgnarTrowbridge et al. 1992, 1993, 1996, Aronica \& Katzenellenbogen 1993, Musgrove et al. 1993, Foster \& Wimalasena 1996, Hafner et al. 1996,
El-Tanani \& Green 1997, Lee et al. 1997, Planas-Silva \& Weinberg 1997, Prall et al. 1997, Pratt et al. 1998, W. Wang et al. 1998, Wilding et al. 1988). Although insulin/growth factor polypeptides and $\mathrm{E}_{2}$ induce cell proliferation and gene expression through distinct receptors and their downstream signaling pathways, growth factor-ER crosstalk has been observed in ER-positive breast cancer cells and other $\mathrm{E}_{2}$-responsive tissues such as the rodent uterus. For example, both $\mathrm{E}_{2}$, IGF and EGF induce a similar pattern of uterotrophic responses in female mouse uterus (Gannon et al. 1976, Das et al. 1994); however, in ER $\alpha$ knockout mice, EGF-induced DNA synthesis and progesterone receptor (PR) gene expression were absent (Curtis et al. 1996). Moreover, the estrogen-like activity of EGF in the uterus was inhibited by antiestrogen ICI 164384 .

Growth factors such as IGF-I induce proliferation and/or DNA synthesis of ER-positive breast cancer cells, and these responses are inhibited by phosphatidylinositol-3-kinase (PI3-K) inhibitors such as wortmanin and LY294002, the phorbol ester 12-O-tetradecanoylphorbol-13-acetate, and antiestrogens (Vignon et al. 1987, Wakeling et al. 
1989, Freiss et al. 1990, Ignar-Trowbridge et al. 1992, 1993, 1996, Aronica \& Katzenellenbogen 1993, de Cupis et al. 1995, Hafner et al. 1996, Dufourny et al. 1997, El-Tanani \& Green 1997, Lee et al. 1997, Kato et al. 1998, Weigel \& Zhang 1998, Ahmad et al. 1999, Zimmermann \& Moelling 1999, Wang et al. 2000). Inhibition of growth factorinduced proliferation by antiestrogens demonstrates that some of the mitogenic activity of IGF-I is linked to regulation of estrogen-responsive genes. Growth factors mediate transcriptional activation of constructs containing estrogen-responsive element (ERE) promoter inserts and activation of estrogenresponsive genes through kinase-dependent phosphorylation of $\operatorname{Ser}^{118}$ or $\operatorname{Ser}^{167}$ of $\mathrm{ER} \alpha$ in the absence of estrogen (Kato et al. 1995, 1998, Joel et al. 1998). Thus, growth factor induction of kinase pathways causes ligand-independent activation of ER and some ER-dependent genes.

Research in this laboratory has identified a number of $\mathrm{E}_{2}$-responsive genes which are ligand $\left(\mathrm{E}_{2}\right)$-activated through interaction of $\mathrm{ER} \alpha / \mathrm{Sp} 1$ with specific GC-rich promoter elements. This induction process involves $\mathrm{ER} \alpha$-protein (Sp1) but not ER $\alpha-D N A$ interactions and gene promoters that are induced by this pathway include cathepsin D, E2F1, IGF binding protein 4, retinoic acid receptor $\alpha 1$, thymidylate synthase, adenosine deaminase (ADA), c-fos and bcl-2 (Porter et al. 1996, Duan et al. 1998, Sun et al. 1998, Wang et al. 1998, W. Wang et al. 1999, Dong et al. 1999, Qin et al. 1999, Xie et al. 1999, 2000). Recent reports also suggest that the ER $\alpha / \mathrm{Sp} 1$ pathway may also be important for induction of the human PR, EGF receptor, and receptor for advanced glycation end products (Petz \& Nardulli 2000, Salvatori et al. 2000, Tanaka et al. 2000). The ADA gene is involved in nucleotide metabolism (Aronow et al. 1992, Dusing \& Wiginton 1994), and this study uses ADA as a model to investigate mechanisms of growth factor activation of $\mathrm{ER} \alpha / \mathrm{Sp} 1$-dependent genes in breast cancer cells (Xie et al. 1999). The results show that IGF-I-induced expression of ADA in MCF-7 cells is associated with ligand-independent $\mathrm{ER} \alpha$ activation and interactions of $\mathrm{ER} \alpha / \mathrm{Sp} 1$ with multiple $\mathrm{GC}$-rich sites in the proximal promoter region of the ADA gene promoter.

\section{MATERIALS AND METHODS}

\section{Chemicals, MCF-7 cells and oligonucleotides}

MCF-7 cells were obtained from the American Type Culture Collection (ATCC, Manassas, VA, USA). Cells were routinely maintained in minimal essential medium with phenol red and supplemented with $10 \%$ fetal bovine serum plus a $1 \%$ antibiotic-antimycotic solution (Sigma Chemical Co., St Louis, MO, USA) in an air:carbon dioxide (95:5) atmosphere at $37^{\circ} \mathrm{C}$. For transient transfection studies, cells were grown for 1 day in DME/F12 medium without phenol red and 5\% fetal bovine serum treated with dextran-coated charcoal. The constructs pADA211, pADA84 and pADA56 contained ADA gene promoter inserts linked to a bacterial chloramphenicol acetyltransferase (CAT) reporter gene and were provided by $\mathrm{Dr}$ Dan A Wiginton (University of Cincinnati College of Medicine and Children's Hospital Research Foundation, Cincinnati, OH, USA) or previously prepared in this laboratory (Dusing \& Wiginton 1994, Xie et al. 1999). The wild-type human ER $\alpha$ (hER) expression plasmid was provided by $\mathrm{Dr}$ Ming-Jer Tsai (Baylor College of Medicine, Houston, TX, USA). The dominant negative Sp1 plasmid pEBG-Sp1 was provided by Dr G Thiel (University of Cologne, Cologne, Germany). Serine $\mathrm{ER} \alpha$ mutants, HEGO-S ${ }^{118}, \mathrm{HEGO}-\mathrm{S}^{167}$, and HEGO-S ${ }^{118 / 167}$, were kindly provided by Dr D Lannigan (Center for Cell Signaling, University of Virginia, Charlottesville, VA, USA) (Joel et al. 1998). pC3-luc containing the -1806 to +58 from the human complement $\mathrm{C} 3$ gene promoter was kindly provided by Dr Donald McDonnell, Department of Pharmacology, Duke University (Durham, NC, USA) (Norris et al. 1996). PD98059 and LY294002 were purchased from Calbiochem Co. (La Jolla, CA, USA). The inhibitory MAPK (mitogen-activated protein kinase) construct was kindly provided by Dr A Gutierrez-Hartmann (University of Colorado, Denver, CO, USA) (Conrad et al. 1994) and the dominant negative Ras was kindly provided by Dr J Baldassare (St Louis University, St Louis, MO, USA) (Weber et al. 1997). $\beta$-Galactosidase activity in cotransfection studies was determined using an assay kit purchased from InVitrogen (Carlsbad, CA, USA). Acetic acid $(0 \cdot 1 \mathrm{M})$ was used as solvent for growth factors, EGF, IGF and TGF $\alpha$ which were purchased from Sigma Chemical Co. All other chemicals and biochemicals were the highest quality available from commercial sources.

Oligonucleotides derived from the ADA gene promoter and a consensus Sp1 oligonucleotide were synthesized by the Gene Technologies Laboratory, Texas A\&M University (College Station, TX, USA). Structures of these oligonucleotides (sense strands) are summarized below and the putative GC-rich sites are underlined. Mutations incorporated in the mutant oligonucleotides are denoted by an asterisk. 
ADASp1·4 (-86/-65)

5'-AGC TTG GCG AGA GGG CGG GCC CCG GGA G-3' ADASp1.4 m (-86/-65)

5'-AGC TTG GCG AGA GT*T* A*A*A* GCC CCG GGA G-3' Sp1 (consensus)

5'-AGC TTA TTC GAT CGG GGC GGG GCG AGC G-3'

\section{Cloning}

The pBLTATA-CAT plasmid was made by digesting the pBLCAT2 vector with BamHI and XhoI to remove the thymidine kinase promoter; the double-stranded E1B oligonucleotide containing complementary $5^{\prime}$ overhangs was then inserted into the corresponding sites. ADASp1.4 and ADASp $1.4 \mathrm{~m}$ oligonucleotides were cloned into the pBLTATA-CAT vector at the HindIII and BamHI sites to give the pADASp1.4 and pADASp1.4 m constructs respectively, as described (Xie et al. 1999).

\section{Northern blot analysis}

ADA and $\beta$-tubulin gene cDNAs were purchased from ATCC. ADA mRNA levels were measured by using a $1.1 \mathrm{~kg}$ HindIII fragment of the human ADA cDNA. $\beta$-Tubulin mRNA levels were measured by using a $1.1 \mathrm{~kg}$ EcoRI fragment of human $\beta$-tubulin cDNA. RNA was extracted from MCF-7 cells after treatment with vehicle (control) or $10 \mathrm{nM}$ IGF using the RNAzol B method (Tel-Test Inc., Friendswood, TX, USA) followed by electrophoretic separation on a $1 \cdot 2 \%$ agarose gel, then transferred to a nylon membrane. The membrane was then exposed to u.v. light for 5 min to crosslink RNA to the membrane and baked at $80{ }^{\circ} \mathrm{C}$ for $2 \mathrm{~h}$. The membrane was prehybridized in a solution containing $0 \cdot 1 \%$ BSA, $0 \cdot 1 \%$ Ficoll, $0 \cdot 1 \%$ polyvinylpyrollidone, $10 \%$ dextran sulfate, $1 \%$ SDS and $5 \times \operatorname{SSPE}\left(0.75 \mathrm{M} \mathrm{NaCl}, 50 \mathrm{mM} \mathrm{NaH} \mathrm{PO}_{4}, 5 \mathrm{mM}\right.$ EDTA) for $18-24 \mathrm{~h}$ at $65{ }^{\circ} \mathrm{C}$ and hybridized in the same buffer for $24 \mathrm{~h}$ with the ${ }^{32} \mathrm{P}$-labeled DNA probe $\left(10^{6}\right.$ c.p.m. $\left./ \mathrm{ml}\right)$. DNA probes were labeled with $\alpha-{ }^{32} \mathrm{P}-\mathrm{dCTP}$ using the random primed DNA labeling kit (Boehringer-Mannheim, Indianapolis, IN, USA). The resulting blots were quantitated using an Instant Imager System (Packard Instruments, Downers Grove, IL, USA) and visualized by autoradiography using X-Omat film (Eastman Kodak, Co., Rochester, NY, USA). ADA mRNA levels were standardized against $\beta$-tubulin mRNA.

\section{Transient transfection assay}

MCF-7 cells were transfected utilizing the calcium phosphate method with $10 \mu \mathrm{g}$ of the ADA gene promoter-derived constructs and $5 \mu \mathrm{g}$ of wild-type or variant ER expression plasmids; in the absence of cotransfected wild-type ER, no hormoneresponsiveness was observed and this was due to overexpression of the ADA promoter-derived constructs. $\beta$-Galactosidase-lac $Z$ plasmid $(5 \cdot 0 \mu \mathrm{g})$ obtained from InVitrogen was cotransfected in studies determining differences in basal CAT activities with constructs containing ADA gene promoter inserts; activities were corrected for transfection efficiencies. pCDNA3-Neo (InVitrogen) was utilized as an empty vector (control) and was also added in some experiments to maintain uniform levels of added DNA. Transfection efficiency was high and no additional shock was required. After $18 \mathrm{~h}$, media were changed and cells were treated with vehicle $(0 \cdot 1 \mathrm{M}$ acetic acid), different concentrations of EGF, IGF or TGFa alone or in combination with inhibitors PD98059 $(50 \mathrm{nM})$ or LY294002 $(50 \mu \mathrm{M})$ for $44 \mathrm{~h}$. Cells were then washed with PBS and scraped from the plates. Cell lysates were prepared in $0.15 \mathrm{ml}$ of $0.25 \mathrm{M}$ Tris- $\mathrm{HCl}(\mathrm{pH} 7 \cdot 5)$ by three freeze-thaw-sonication cycles (3 min each). Protein concentrations were determined using BSA as a standard and analysis for CAT activity in cell lysates utilized a constant amount of protein from each treatment group. Lysates were incubated at $56{ }^{\circ} \mathrm{C}$ for $7 \mathrm{~min}$ to remove endogenous deacetylase activity. CAT activity was determined by incubating aliquots of the cell lysates with $0.2 \mathrm{mCi}$ D-threo-[dichloroacetyl$\left.1-{ }^{14} \mathrm{C}\right]$ chloramphenicol and $4 \mathrm{mM}$ acetyl CoA. Acetylated products were visualized and quantitated using an Instant Imager System (Packard Instruments). CAT activity in various treatment groups was calculated as fraction of that observed in cells treated with vehicle alone (arbitrarily set at 100) and results are expressed as means \pm S.D. At least three separate experiments were carried out for each treatment group.

\section{Western immunoblotting}

Nonphosphorylated and phosphorylated Erk-1, and Akt antibodies were purchased from New England Biolabs (Beverly, MT, USA). MCF-7 cells were incubated in serum-free media for $36 \mathrm{~h}$ and were then treated with $10 \mathrm{nM}$ IGF in the presence or absence of $50 \mathrm{nM}$ PD98059 or $50 \mu \mathrm{M}$ LY294002 for $10 \mathrm{~min}$. Cells were washed once in ice-cold PBS and collected by scraping in $0.3 \mathrm{ml}$ ice-cold lysis buffer

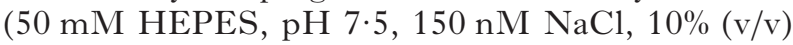
glycerol, $1 \%$ Triton X-100, $1.5 \mathrm{mM} \mathrm{MgCl}_{2}, 1 \mathrm{mM}$ EGTA, $10 \mu \mathrm{g} / \mathrm{ml}$ aprotinin, $50 \mathrm{mM}$ phenylmethylsulfonylfluoride, $50 \mathrm{mM}$ sodium orthovanadate). The lysates were incubated on ice for $1 \mathrm{~h}$ with intermittent vortexing followed by centrifugation 
(15 $000 \mathrm{~g}, 5 \mathrm{~min})$. Equal amounts of protein from each treatment group were separated by SDSPAGE $(7 \cdot 5 \%$ gel, $150 \mathrm{~V})$ and electrophoresed (15 V, overnight) to a PVDF membrane using a BioRad Trans-Blot Electrophoretic Transfer Cell (BioRad, Hercules, CA, USA); the transfer buffer was $48 \mathrm{mM}$ Tris, $39 \mathrm{mM}$ glycine, $0.025 \%$ SDS. Subsequent procedures followed the manufacturer's recommendations (New England Biolabs).

\section{Statistics}

Results are expressed as means \pm s.D. for three separate determinations for each data point. Statistical significance $(P<0.05)$ was determined by performing ANOVA and Scheffé's post hoc test.

\section{RESULTS}

\section{Activation of ADA by growth factors in MCF-7 cells}

Initial studies showed that IGF induced ADA gene expression ( $>2 \cdot 50$-fold) in MCF-7 cells, thus confirming that both growth factors and $\mathrm{E}_{2}$ (Xie et al. 1999) induce this gene (Fig. 1A). Previous studies have demonstrated that a $232 \mathrm{bp}$ region encompassing the -211 to +11 region of the ADA gene promoter confers high basal activity on reporter genes after transfection in several different cell lines including MCF-7 cells and in transgenic mouse studies (Aronow et al. 1992, Dusing \& Wiginton 1994, Xie et al. 1999). In transfection studies in MCF-7 cells using pADA211 (containing the -211 to +11 ADA gene promoter insert), $10 \mathrm{nM}$ concentrations of $\mathrm{E}_{2}, \mathrm{EGF}, \mathrm{IGF}$ and TGF $\alpha$ alone did not induce CAT (reporter gene) activity. Previous studies showed that $\mathrm{E}_{2}$-responsiveness of this construct was dependent on cotransfection with $\mathrm{ER} \alpha$ in MCF-7 cells due to high overexpression of the construct in transfected cells resulting in insufficient amounts of endogenous ER $\alpha$. Similar results have been observed with other $\mathrm{E}_{2}$-responsive genes containing functional GC-rich sites for $\mathrm{ER} \alpha / \mathrm{Sp} 1$ interactions (Porter et al. 1996, Duan et al. 1998, Sun et al. 1998, F. Wang et al. 1998, W. Wang et al. 1999, Dong et al. 1999, Qin et al. 1999, Xie et al. 1999, 2000) and also constructs derived from nonconsensus ERE-dependent genes including $\mathrm{pS} 2, \mathrm{c}-\mathrm{myc}$, cathepsin $\mathrm{D}$, retinoic acid receptor $\alpha 1$, and the progesterone receptor (PR) (Savouret et al. 1991, Dubik \& Shiu 1992, Cavailles et al. 1993, Krishnan et al. 1994, Zacharewski et al. 1994, Rishi et al. 1995, Wang et al. 1997). Treatment of MCF-7 cells with $10 \mathrm{nM} \mathrm{E}_{2}$ and IGF after cotransfection with pADA211 plus ER $\alpha$ expression plasmid resulted in induction of CAT activity whereas, at this concentration, a significant induction response was not observed for TGF $\alpha$ or EGF. Previous studies reported a similar differential growth factor (IGF vs TGF $\alpha / E G F$ ) induction response using $\mathrm{E}_{2}$-responsive constructs containing cathepsin D gene promoter inserts (Vignon et al. 1987, Freiss et al. 1990, Wang et al. 2000). However, the results summarized in Fig. 1C show that over a wider range of doses all three growth factors activate pADA211 in MCF-7 cells (cotransfected with $\mathrm{ER} \alpha$ ), but IGF is the most potent inducer.

The -211 to +11 region of the $\mathrm{ADA}$ gene promoter contains multiple GC-rich sites, and only one of these sites at -79 to -73 (site IV) is required for hormone-induced $\mathrm{ER} \alpha / \mathrm{Sp} 1$ action. IGF induces CAT activity in MCF-7 cells transfected with pADA211, pADA81 and pADA56 (Fig. 2A), and only the former two constructs contain $\mathrm{GC}$-rich site IV that is required for $\mathrm{E}_{2}$-responsiveness, suggesting that IGF-induced, ligand-independent $\mathrm{ER} \alpha / \mathrm{Sp} 1$ action involves multiple $\mathrm{GC}$-rich sites within the proximal region of the ADA gene promoter. The importance of GC-rich sites and $\mathrm{Sp} 1$ protein were also investigated using pADASp1, a construct containing a single GC-rich sequence (i.e. site IV) and a second plasmid mutated in the GC-rich sites. IGF induced CAT activity only with pADASp1, indicating that an induction response required an intact $\mathrm{Sp} 1$ binding site. The importance of $\mathrm{Sp} 1$ protein in mediating IGF-induced transactivation of pADA211 was confirmed by showing that the induced response in MCF-7 cells transfected with a dominant negative form of $\mathrm{Sp} 1$ (pEBG-Sp1) was significantly decreased (Fig. 2B). Thus, growth factor-induced transactivation of pADA211 requires both ER $\alpha$ and $\mathrm{Sp} 1$ proteins and one or more $\mathrm{GC}$-rich promoter elements.

\section{Role of IGF-induced phosphorylation of ERa}

The role of growth factor-induced MAPK signaling on ligand-independent $\mathrm{ER} \alpha / \mathrm{Sp} 1$ action was determined in MCF-7 cells transfected with ER $\alpha$ expression plasmid, pADA211 and treated with the MAPK kinase inhibitor PD98059 (Fig. 3A) or cotransfected with dominant negative Ras or MAPK expression plasmids (Fig. 3B). The results show that PD98059 and both dominant negative expression plasmids inhibit IGF-induced reporter gene activity and confirm the importance of MAPK activation. Previous studies showed that phosphorylation of $\operatorname{Ser}^{118}$ and $\operatorname{Ser}^{167}$ are important for ligand-independent activation of $\mathrm{ER} \alpha$ by growth 


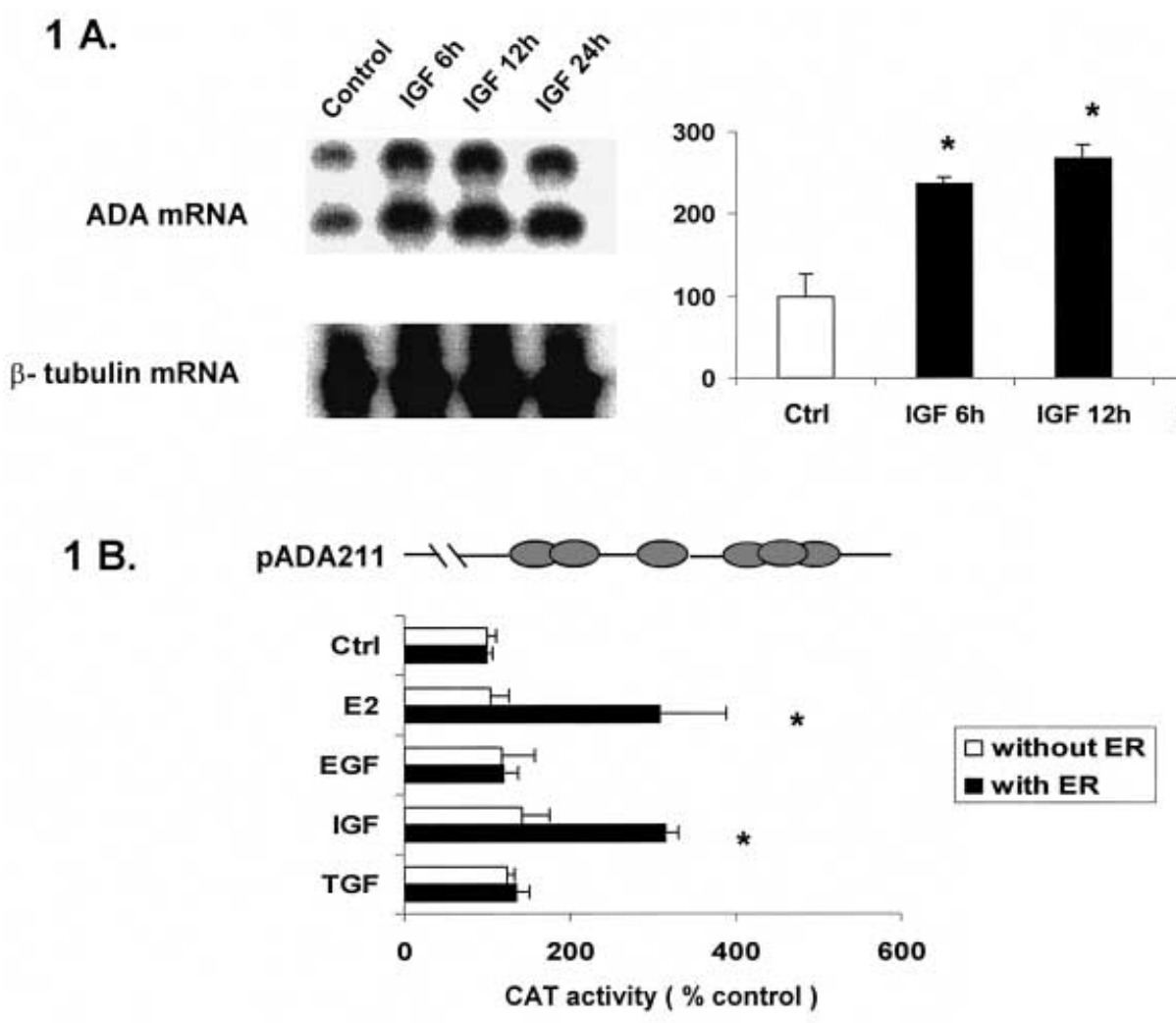

$1 \mathrm{C}$.

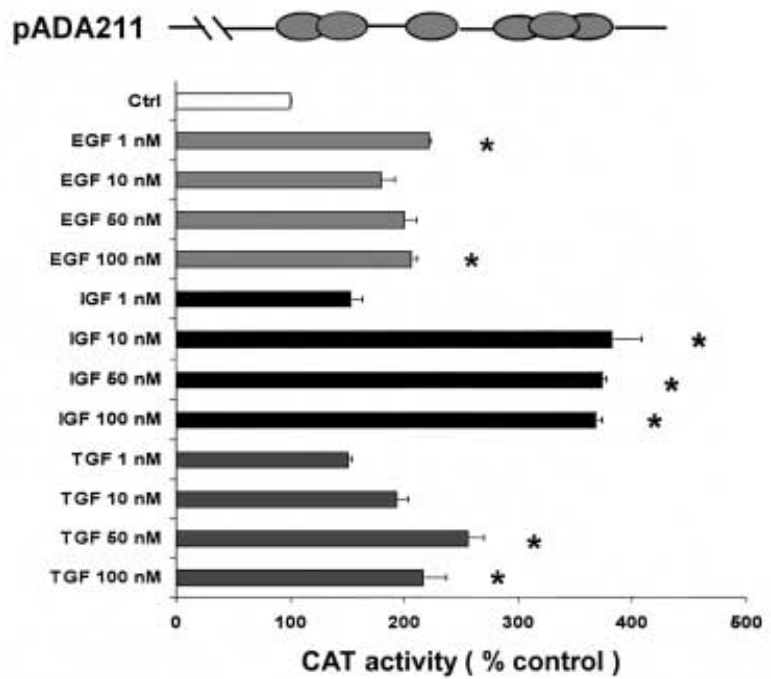

FIGURE 1. Transcriptional activation of ADA in MCF-7 cells. (A) Induction of ADA mRNA levels. MCF-7 cells were treated with $10 \mathrm{nM}$ IGF for 6, 12 and $24 \mathrm{~h}$, and ADA mRNA levels were determined by Northern blot analysis as described in the Materials and Methods. Both bands were used for determining mRNA levels in each treatment group. Significant induction $(P<0 \cdot 05)$ was observed at all time points. $(\mathrm{B} / \mathrm{C})$ Activation of pADA211 by growth factors. MCF-7 cells were transfected with pADA211 in the presence or absence of ER $\alpha$ expression plasmids, treated with $10 \mathrm{nM} \mathrm{E}_{2}$ or growth factors (B) or different concentrations of growth factors (C), and CAT activity was determined as described in the Materials and Methods. Significant induction $(P<0 \cdot 05)$ compared with vehicle control is indicated with an asterisk. Results are expressed as means \pm s.D. for three separate experiments for each treatment group. ${ }^{*} P<0 \cdot 05$. 


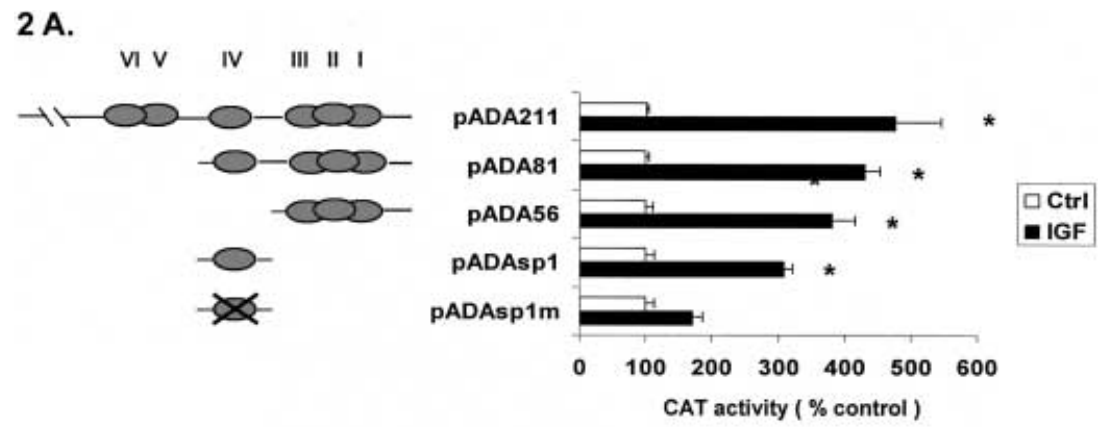

2 B.

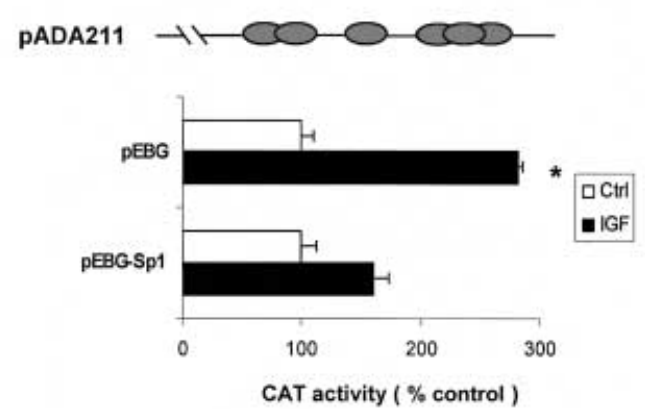

FIGURE 2. Induction of ADA promoter constructs by IGF. (A) Deletion analysis. Different constructs were transfected into MCF-7 cells, treated with $10 \mathrm{nM}$ IGF and CAT activity determined as described in the Materials and Methods. Significant induction $(P<0 \cdot 05)$ was observed for all constructs except pADAsp1m. (B) Effects of dominant negative Sp1 expression (pEBG-Sp1). MCF-7 cells were transfected with pADA211 and empty vector (pEBG) or dominant negative Sp1 expression plasmid (pEBG-Sp1), treated with 10 nM IGF, and CAT activity was determined as described in the Materials and Methods. IGF significantly $(P<0 \cdot 05)$ induced CAT activity and this response was blocked by dominant negative $\mathrm{Sp} 1$. Results are expressed as means \pm S.D. for at least three separate experiments for each treatment group. $* P<0 \cdot 05$.

factors and are required for ERE-dependent transactivation (Kato et al. 1995, Joel et al. 1998). The roles of $\operatorname{Ser}^{118}$ and $\operatorname{Ser}^{167}$ in IGF activation were determined in MCF-7 cells transfected with pADA211, wild-type ER $\alpha$, or the serine mutant $\mathrm{mER} \alpha-\mathrm{S} 118, \mathrm{mER} \alpha-\mathrm{S} 167$ and $\mathrm{mER} \alpha-\mathrm{S} 118 / 167$ (both serines mutated) expression plasmids. The results showed that IGF-mediated transactivation was observed only with wild-type $\mathrm{ER} \alpha$ and that mutation of either $\operatorname{Ser}^{118}$ or $\operatorname{Ser}^{167}$ resulted in loss of ligand-independent $\mathrm{ER} \alpha / \mathrm{Sp} 1$ action (Fig. 3C). In contrast, all three Ser mutants of ER $\alpha$ activated the human C3-luc construct in MCF-7 cells treated with $10 \mathrm{nM} \mathrm{E}$ (Fig. 3D).

\section{IGF activation of Akt and MAPK and induction of pADA211}

The interplay between IGF and activation of phosphatidylinositol-3 kinase (PI3-K), Akt and MAPK kinase pathways in breast cancer cells has previously been reported (Dufourny et al. 1997,
Ahmad et al. 1999, Zimmermann \& Moelling 1999) and the results in Fig. 4A,B summarize the effects of IGF on phosphorylation of Erk-1, Erk-2 and Akt. Ten nM IGF alone induces phosphorylation of Erk-1, Erk-2 and Akt and, in cells cotreated with IGF plus the MAPKK inhibitor PD98059, there was significant inhibition of Erk-1 and Erk-2 phosphorylation, whereas levels of immunoreactive Akt phosphoprotein were unchanged. In contrast, cotreatment with IGF and the PI3 kinase inhibitor LY294002 resulted in enhanced phosphorylation of Erk-1 and Erk-2 and inhibition of Akt phosphorylation. Enhanced phosphorylation of Erk-1 and Erk-2 in breast cancer cells by LY294002 has previously been reported by Zimmerman \& Moelling (1999) who also showed that this was accompanied by increased Raf kinase-dependent activity. The results in Fig. 4 indicate that IGF stimulation of Akt phosphorylation is not required for activation of pADA211 and the results also show that levels of Erk-1/-2 phosphorylation (Fig. 3A) do not correlate with pADA211 activation (Fig. 3C). 
pADA211

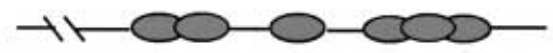

3 A.

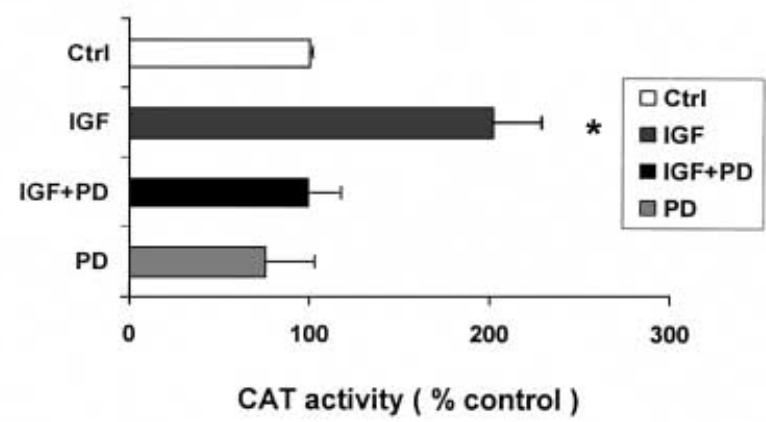

$3 \mathrm{C}$.

pADA211

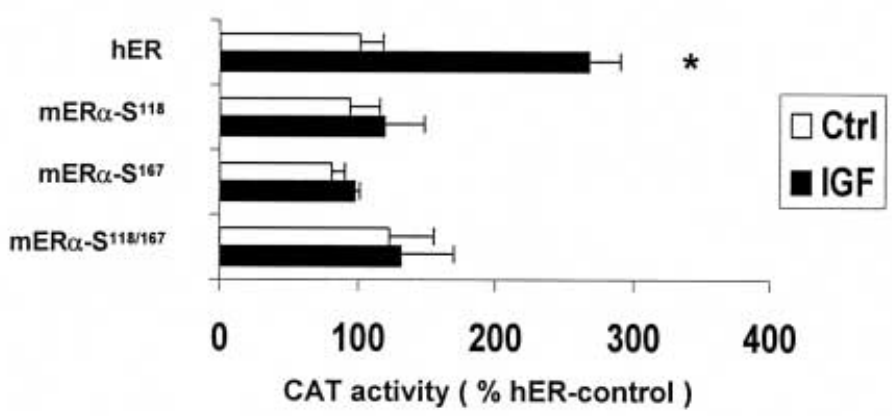

3 B.

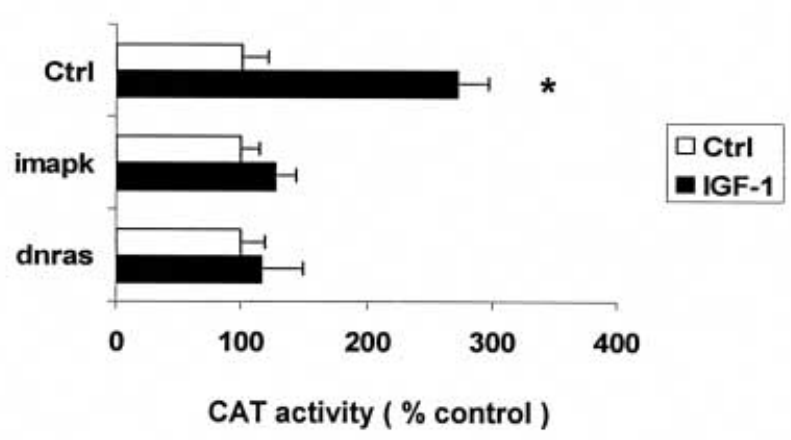

3 D. pC3-Luc

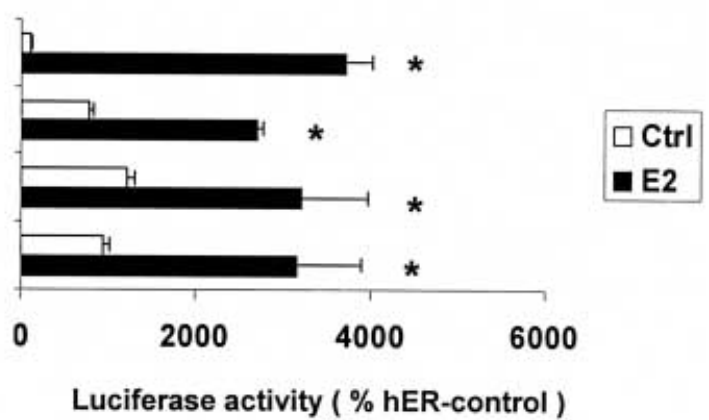

FIGURE 3. IGF activation of pADA211: effects of kinase inhibitors and $\operatorname{Ser}^{118}$ and $\operatorname{Ser}^{167}$ ER $\alpha$ mutants. MCF-7 cells were transfected with ER $\alpha$ expression plasmid, pADA211, and treated with $10 \mathrm{nM} \mathrm{IGF}$ and PD98059 (A) and dominant negative ras (dnRas) or inhibitory MAPK (iMAPK) expression plasmids (B), and CAT activity was determined as described in the Materials and Methods. IGF-induced activity was significantly inhibited $(P<0 \cdot 05)$ after treatment with PD98059, dominant negative ras, or inhibitory MAPK expression plasmids. (C) Activation using Ser mutants of ER $\alpha$. Activation of pADA211 was carried out as described above except that cells were cotransfected with ER $\alpha$ expression plasmids mutated at serines 118 and/or 167. Induction was not observed using mutant ER $\alpha$ expression plasmids. (D) Activation of $\mathrm{pC} 3$-luc. Using the same protocol as described above, $\mathrm{E}_{2}$ significantly activated pC3-luc in MCF-7 cells cotransfected with ER $\alpha$ or serine mutants of ER $\alpha$, demonstrating that these ER $\alpha$ mutants were active in this cell line. Results are expressed as means \pm s.D. ${ }^{*} P<0 \cdot 05$.

For example, in MCF-7 cells transfected with pADA211, treatment with $50 \mu \mathrm{M}$ LY294002 plus IGF induced CAT activity similar to that observed after treatment with IGF alone (Fig. 4C), even though the cotreatment resulted in significantly higher Erk-1/-2 phosphorylation (Fig. 4A). Nevertheless, these data indicate that ligand-independent activation of pADA211 by IGF is primarily dependent on the ras-MAPK pathway and phosphorylation of the AF1 domain of $\mathrm{ER} \alpha$ (Fig. 5).

\section{DISCUSSION}

Growth factor polypeptides, insulin and $\mathrm{E}_{2}$ induce proliferation of ER-positive cancer cells lines, and pure antiestrogens such as ICI 182780 can inhibit both $\mathrm{E}_{2}$ - and growth factor-mediated cell proliferation (Wakeling et al. 1989, Freiss et al. 1990, de Cupis et al. 1995, Ahmad et al. 1999, Zimmermann \& Moelling 1999). Peptide growth factor activation of $\mathrm{ER} \alpha$ and $\mathrm{E}_{2}$-responsive genes has been observed 
$4 A$.

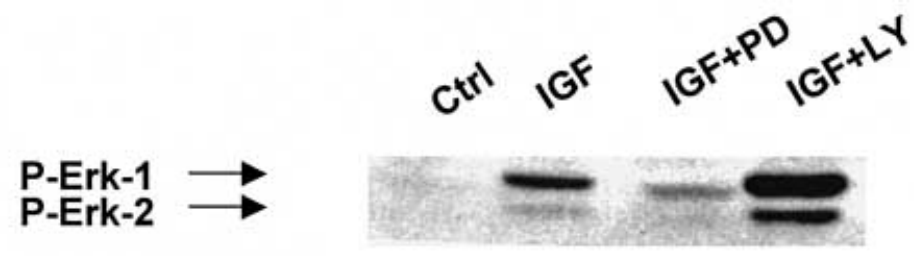

Erk-1

Erk-2
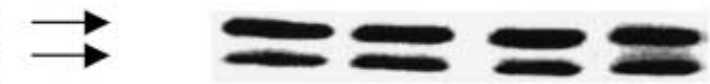

4B.

4C.
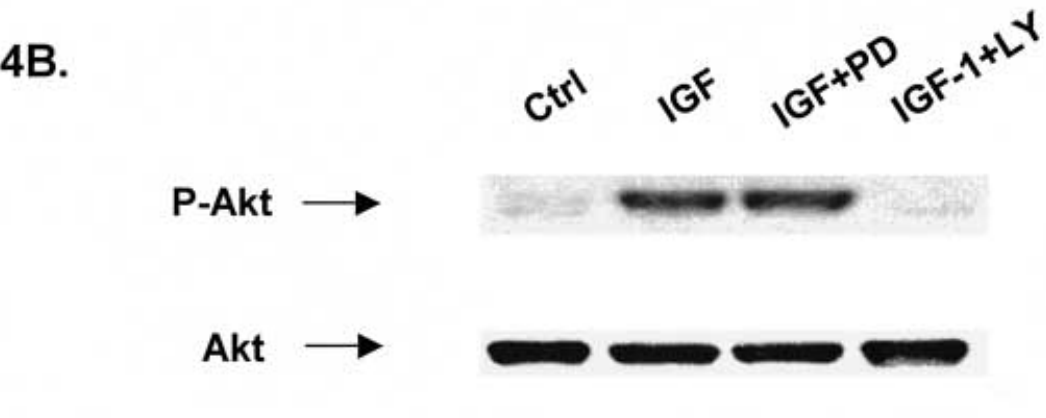

pADA211

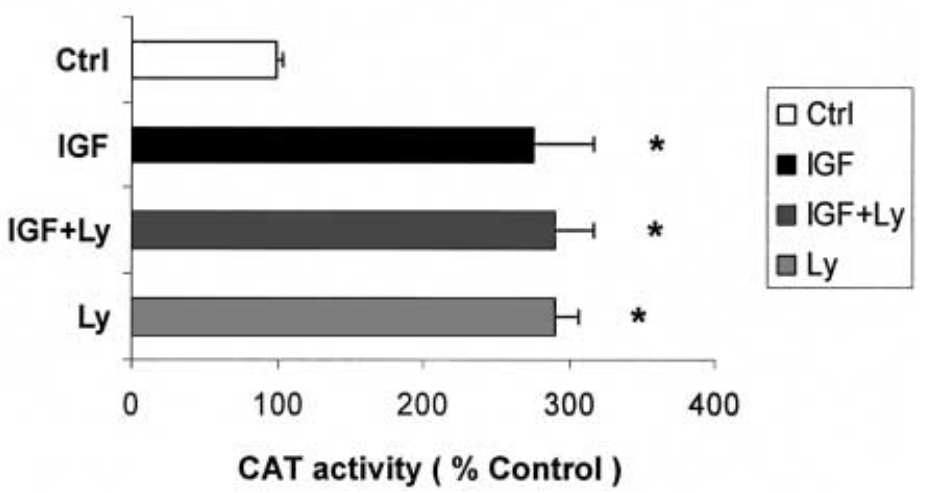

FIGURE 4. Modulation of kinases and pADA211 by IGF. Activation of Erk-1/-2 (A) and Akt (B) by IGF. Whole cell extracts were obtained from MCF-7 cells treated with solvent control (Ctrl), $10 \mathrm{nM}$ IGF in the presence or absence of $50 \mathrm{nM}$ PD98059 or $50 \mu \mathrm{M}$ LY294002, and immunoblot analyses of phosphorylated ERK-1/-2 and Akt, and their total proteins were carried out as described in the Materials and Methods. PD98059 inhibited IGF-induced phosphorylation of Erk-1/-2 but not Akt; LY294002 enhanced IGF-induced phosphorylation of Erk-1/-2 but inhibited Akt phosphorylation. Total immunoreactive Akt and Erk-1/-2 were not affected by the various treatments. (C) Effects of LY294002 on pADA211 activation by IGF. MCF-7 cells were transfected with pADA211 and $10 \mathrm{nM}$ IGF, $50 \mu \mathrm{M}$ LY294002, and their combination significantly $(P<0 \cdot 05)$ induced CAT activity; results are expressed as means \pm S.D. for three separate determinations. $* P<0 \cdot 05$. 


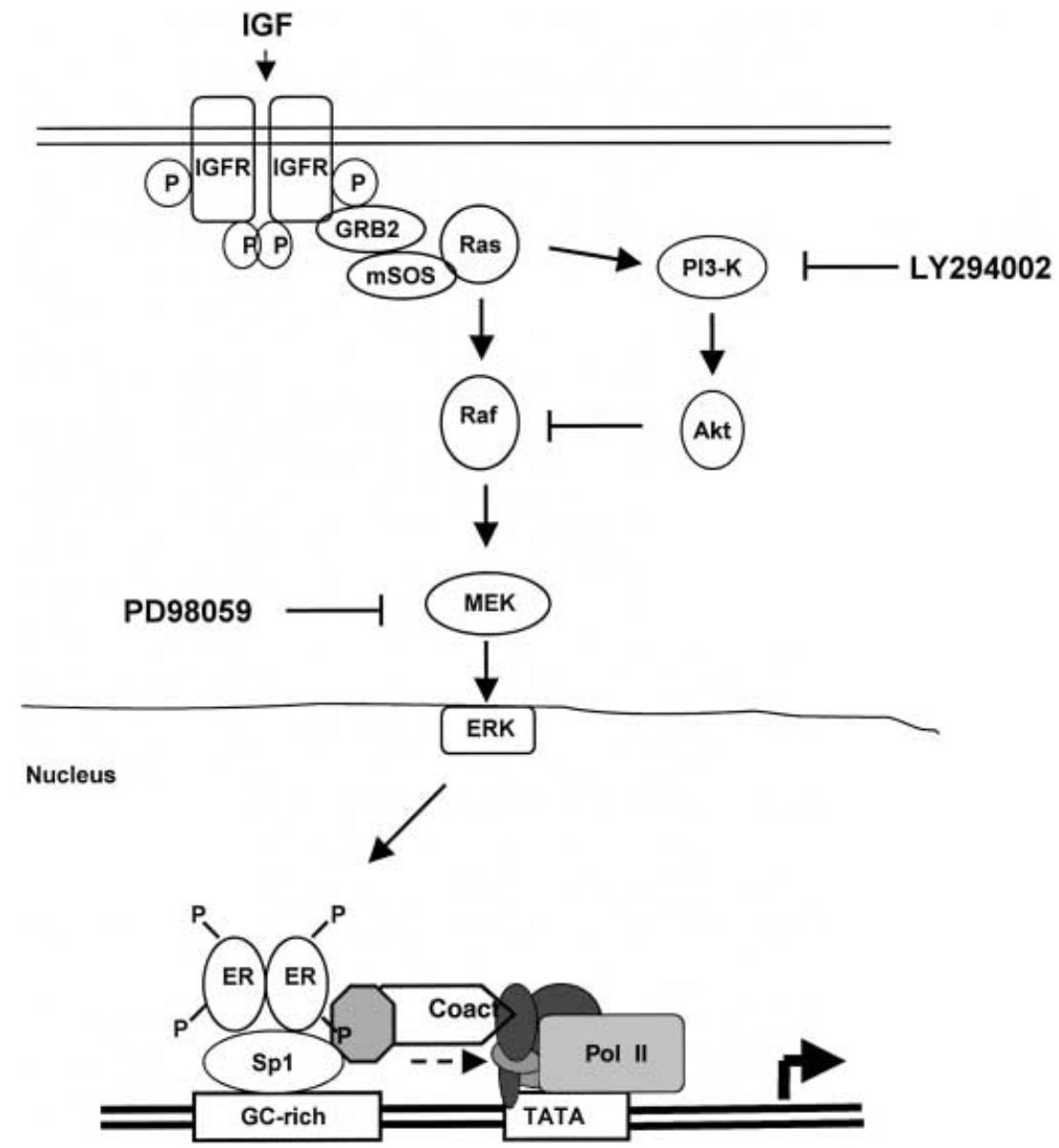

FIGURE 5. Pathways for growth factor activation of ER $\alpha$ and ADA expression in MCF-7 cells.

in several studies (Cavailles et al. 1989, IgnarTrowbridge et al. 1992, 1993, 1996, Aronica \& Katzenellenbogen 1993, Kato et al. 1995, Hafner et al. 1996, El-Tanani \& Green 1997, Lee et al. 1997, Joel et al. 1998). Growth factor activation of $\mathrm{ER} \alpha$ and subsequent ligand-independent transactivation of ERE-dependent constructs is associated with phosphorylation of $\operatorname{Ser}^{118}$ and/or $\operatorname{Ser}^{167}$ in activation function 1 (AF1) (Kato et al. 1995, Joel et al. 1998). A recent study in this laboratory demonstrated that in MCF-7 cells transiently transfected with $\mathrm{E}_{2}$-responsive constructs derived from the cathepsin $\mathrm{D}$ gene promoter, IGF activated gene expression through different response elements including at least four GC-rich sites (Wang et al. 2000). Moreover, IGF activated ER $\alpha / \mathrm{Sp} 1$ (ligandindependent) through binding GC-rich elements that were not functional for ligand-dependent activation of the same constructs in the MCF-7 cells (Krishnan et al. 1994, F. Wang et al. 1997, F. Wang et al. 1998).

www.endocrinology.org
The proximal region $(-211$ to +11$)$ of the $\mathrm{ADA}$ gene promoter contains six (I-VI) GC-rich sites that bind $\mathrm{Sp} 1$ protein and are required for high basal gene expression (Aronow et al. 1992, Dusing \& Wiginton 1994, Xie et al. 1999). $\mathrm{E}_{2}$ induces ADA gene expression and analysis of the $\mathrm{ADA}$ gene promoter showed that only GC-rich site IV ( -79 to -73) was important for functional $\mathrm{ER} \alpha / \mathrm{Sp} 1$ interactions (Xie et al. 1999). IGF, EGF and TGF $\alpha$ induced reporter gene activity in MCF-7 cells transfected with pADA211 (Fig. 1B); IGF was the most active growth factor in the transient transfection assays, and IGF also induced ADA mRNA levels (Fig. 1A). Growth factor induction in cells transfected with pADA211 was dependent on cotransfection with ER $\alpha$ (Fig. 1B), and the results obtained with PD98059 (a MAPKK inhibitor) (Fig. 3A), dominant negative Ras, and MAPK expression plasmids (Fig. 3B) are consistent with growth factor activation of ER $\alpha$ through the Ras-MAPK pathway. $\mathrm{E}_{2}$ activates functional $\mathrm{ER} \alpha / \mathrm{Sp} 1$ interactions 
only at site IV in the ADA gene promoter in MCF-7 cells (Xie et al. 1999), whereas results of this study (Fig. 2A) suggest that multiple GC-rich sites within the -211 to +11 region of the promoter are functional for growth factor-induced $\mathrm{ER} \alpha / \mathrm{Sp} 1$ action (ligand-independent). Moreover, mutation of $\operatorname{Ser}^{118}$ or $\operatorname{Ser}^{167}$ in ER $\alpha$ resulted in loss of growth factor-induced activity, confirming previous reports showing the importance of phosphorylation of these amino acid side chains for ligand-independent ER $\alpha$ action (Kato et al. 1995, Joel et al. 1998).

The mechanisms of growth factor activation of $\mathrm{E}_{2}$-responsive genes have not been extensively investigated. IGF induces the ras-MAPK and PI3-K pathways in breast cancer cells, and these responses are blocked not only by specific kinase inhibitors but also by the pure ICI antiestrogens (Ahmad et al. 1999, Razandi et al. 1999). Dufourny and co-workers (1997) reported that the growth stimulatory effects of IGF are accompanied by increased cyclin D1 synthesis and hyperphosphorylation of retinoblastoma protein, and these responses are strongly inhibited by the PI3-K inhibitor LY294002. IGF activation of ras also increases Akt (protein kinase B) phosphorylation in breast cancer cells, and cotreatment with PI3-K inhibitors not only blocked Akt phosphorylation but induced phosphorylation of MAPK. This latter response has been linked to Akt-dependent phosphorylation of Raf-Ser ${ }^{259}$ to give a deactivated form of Raf (Zimmermann \& Moelling 1999) and, thus, inhibition of PI3-K enhanced the MAPK pathway. The results in Fig. 3 demonstrate that transactivation of pADA211 in MCF-7 cells treated with IGF is inhibited by overexpression of dominant negative ras and MAPK and by PD98059 (a MAPKK inhibitor) suggesting that the ras-MAPK pathway plays an important role in ligandindependent activation of $\mathrm{ER} \alpha / \mathrm{Sp} 1$. Kinase inhibition studies indicate that Akt phosphorylation is not important for IGF activation of $\mathrm{ER} \alpha / \mathrm{Sp} 1$; however, increased phosphorylation of Erk-1/-2 does not correlate with increased transactivation of pADA211, and this was particularly evident in cells cotreated with IGF and LY294002. Moreover, the $\mathrm{PI} 3-\mathrm{K}$ inhibitor alone enhances transactivation in cells transfected with pADA211 and current studies are investigating pathways associated with this response.

Previous studies indicated that IGF-induced cell proliferation is blocked by PI3-K inhibitors but not by PD98059 (Dufourny et al. 1997, Ahmad et al. 1999, Zimmermann \& Moelling 1999). This suggests that growth factor activation of ADA in MCF-7 cells through the ras-MAPK pathway may not be critical for cell proliferation. Since genes activated through the PI3-K pathway may be more directly related to growth factor-induced proliferation of MCF-7 cells, we are currently investigating the relative contributions of Ras-P13-K and Ras-MAPK pathways for growth factor activation of several $\mathrm{E}_{2}$-responsive genes as a marker for their roles in the mitogenic response.

\section{ACKNOWLEDGEMENTS}

The financial assistance of the National Institutes of Health (ES09253 and ES09106) and the Texas Agricultural Experiment Station is gratefully acknowledged. S Safe is a Sid Kyle Professor of Toxicology.

\section{REFERENCES}

Ahmad S, Singh N \& Glazer RI 1999 Role of AKT1 in $17 \beta$ estradiol- and insulin-like growth factor I (IGF-I)dependent proliferation and prevention of apoptosis in MCF-7 breast carcinoma cells. Biochemical Pharmacology $\mathbf{5 8}$ $425-430$.

Aronica SM \& Katzenellenbogen BS 1993 Stimulation of estrogen receptor-mediated transcription and alteration in the phosphorylation state of the rat uterine estrogen receptor by estrogen, cyclic adenosine monophosphate, and insulin-like growth factor-I. Molecular Endocrinology 7 743-752.

Aronow BJ, Silbiger RN, Dusing MR, Stock JL, Yager KL, Potter SS, Hutton JJ \& Wiginton DA 1992 Functional analysis of the human adenosine deaminase gene thymic regulatory region and its ability to generate positionindependent transgene expression. Molecular and Cellular Biology 12 4170-4185.

Bates SE, Davidson NE, Valverius EM, Freter CE, Dickson RB, Tam JP, Kudlow JE, Lippman ME \& Salomon DS 1988 Expression of transforming growth factor- $\alpha$ and its messenger ribonucleic acid in human breast cancer: its regulation by estrogen and its possible functional significance. Molecular Endocrinology 2 543-555.

Cavailles V, Garcia M \& Rochefort H 1989 Regulation of cathepsin D and pS2 gene expression by growth factors in MCF-7 human breast cancer cells. Molecular Endocrinology 3 $552-558$

Cavailles V, Augereau P \& Rochefort H 1993 Cathepsin D gene is controlled by a mixed promoter, and estrogens stimulate only TATA-dependent transcription. PNAS 90 203-207.

Conrad KE, Oberwetter JM, Vaillancourt R, Johnson GL \& Gutierrez-Hartmann A 1994 Identification of the functional components of the Ras signaling pathway regulating pituitary cell-specific gene expression. Molecular and Cellular Biology 14 1553-1565.

de Cupis A, Noonan D, Pirani P, Ferrera A, Clerico L \& Favoni RE 1995 Comparison between novel steroid-like and conventional nonsteroidal antioestrogens in inhibiting oestradiol- and IGF-I-induced proliferation of human breast cancer-derived cells. British Fournal of Pharmacology 116 2391-2400.

Curtis SW, Washburn T, Sewall C, DiAugustine R, Lindzey J, Couse JF \& Korach KS 1996 Physiological coupling of growth factor and steroid receptor signaling pathways: 
estrogen receptor knockout mice lack estrogen-like response to epidermal growth factor. PNAS 93 12626-12630.

Das SK, Tsukamura H, Paria BC, Andrews GK \& Dey SK 1994 Differential expression of epidermal growth factor receptor (EGF-R) gene and regulation of EGF-R bioactivity by progesterone and estrogen in the adult mouse uterus. Endocrinology 134 971-981.

Dickson RB \& Lippman ME 1988 Control of human breast cancer by estrogen, growth factors, and oncogenes. In Breast Cancer: Cellular and Molecular Biology, pp 119-166. Eds ME Lippman \& RB Dickson. Boston: Kluwer.

Dickson RB \& Lippman ME 1991 Growth regulation of normal and malignant breast epithelium. In The Breast, pp 363-394. Eds KI Bland \& EM Copeland. Philadelphia: WB Saunders.

Dickson RB \& Lippman ME 1995 Growth factors in breast cancer. Endocrine Reviews 16 559-589.

Dong L, Wang W, Wang F, Stoner M, Reed JC, Harigai M, Kladde M, Vyhlidal C \& Safe S 1999 Mechanisms of transcriptional activation of $b c l-2$ gene expression by $17 \beta$-estradiol in breast cancer cells. Fournal of Biological Chemistry 174 32099-32107.

Duan R, Porter W \& Safe S 1998 Estrogen-induced c-fos protooncogene expression in MCF-7 human breast cancer cells: role of estrogen receptor Sp1 complex formation. Endocrinology 139 1981-1990.

Dubik D \& Shiu RPC 1992 Mechanism of estrogen activation of c-myc oncogene expression. Oncogene 7 1587-1594.

Dufourny B, Alblas J, van Teeffelen HA, van Schaik FM, Van der Burg B, Steenbergh PH \& Sussenbach JS 1997 Mitogenic signaling of insulin-like growth factor I in MCF-7 human breast cancer cells requires phosphatidylinositol 3-kinase and is independent of mitogen-activated protein kinase. Fournal of Biological Chemistry 272 31163-31171.

Dusing MR \& Wiginton DA $1994 \mathrm{Sp} 1$ is essential for both enhancer-mediated and basal activation of the TATA-less human adenosine deaminase promoter. Nucleic Acids Research 22669677.

El-Tanani MK \& Green CD 1997 Two separate mechanisms for ligand-independent activation of the estrogen receptor. Molecular Endocrinology 11 928-937.

Fernandez P, Burghardt R, Smith R, Nodland K \& Safe S 1994 High passage T47D human breast cancer cells: altered endocrine and 2,3,7,8-tetrachlorodibenzo- $p$-dioxin responsiveness. European Fournal of Pharmacology 270 $53-66$.

Foster JS \& Wimalasena J 1996 Estrogen regulates activity of cyclin-dependent kinases and retinoblastoma protein phosphorylation in breast cancer cells. Molecular Endocrinology 10 488-498.

Freiss G, Rochefort H \& Vignon F 1990 Mechanisms of 4-hydroxytamoxifen anti-growth factor activity in breast cancer cells: alterations of growth factor receptor binding sites and tyrosine kinase activity. Biochemical and Biophysical Research Communications 173 919-926.

Furlanetto RW \& DiCarlo JN 1984 Somatomedin C receptors and growth effects in human breast cancer cells maintained in long term tissue culture. Cancer Research 44 2122-2128.

Gannon F, Katzenellenbogen B, Stancel G \& Gorski J 1976 Estrogen-receptor movement to the nucleus: discussion of a cytoplasmic-exclusion hypothesis. Symposium of the Society for Developmental Biology 34 137-149.

Hafner F, Holler E \& von Angerer E 1996 Effect of growth factors on estrogen receptor mediated gene expression. Fournal of Steroid Biochemistry and Molecular Biology $\mathbf{5 8}$ 385-393.

Ignar-Trowbridge DM, Nelson KG, Bidwell MC, Curtis SW, Washburn TF, McLachlan JA \& Korach KS 1992 Coupling of dual signaling pathways - epidermal growth factor action involves the estrogen receptor. PNAS 89 4658-4662.

Ignar-Trowbridge DM, Teng CT, Ross MJ, Parker MG, Korach KS \& McLachlan JA 1993 Peptide growth factors elicit estrogen receptor-dependent transcriptional activation of an estrogen-responsive element. Molecular Endocrinology 7 992-998.

Ignar-Trowbridge DM, Pimentel M, Parker MG, McLachlan JA \& Korach KS 1996 Peptide growth factor cross-talk with the estrogen receptor requires the $\mathrm{A} / \mathrm{B}$ domain and occurs independently of protein kinase $\mathrm{C}$ or estradiol. Endocrinology 137 1735-1744.

Joel PB, Smith J, Sturgill TW, Fisher TL, Blenis J \& Lannigan DA 1998 pp $90^{\text {rsk1 }}$ regulates estrogen receptormediated transcription through phosphorylation of Ser-167. Molecular and Cellular Biology 18 1978-1984.

Karey KP \& Sirbasku DA 1988 Differential responsiveness of human breast cancer cell lines MCF-7 and T47D to growth factors and 17 $\beta$-estradiol. Cancer Research 48 4083-4092.

Kato S, Endoh H, Masuhiro Y, Kitamoto T, Uchiyama S, Sasaki H, Masushige S, Gotoh Y, Nishida E \& Kawashima H 1995 Activation of the estrogen receptor through phosphorylation by mitogen-activated protein kinase. Science 270 1491-1494.

Kato S, Kitamoto T, Masuhiro Y \& Yanagisawa J 1998 Molecular mechanism of a cross-talk between estrogen and growth-factor signaling pathways. Oncology 55 5-10.

Krishnan V, Wang X \& Safe S 1994 Estrogen receptor-Sp1 complexes mediate estrogen-induced cathepsin D gene expression in MCF-7 human breast cancer cells. Fournal of Biological Chemistry 269 15912-15917.

Lee AV, Weng CN, Jackson JG \& Yee D 1997 Activation of estrogen receptor-mediated gene transcription by IGF-I in human breast cancer cells. Fournal of Endocrinology 152 $39-47$.

Musgrove EA, Hamilton JA, Lee CS, Sweeney KJ, Watts CK \& Sutherland RL 1993 Growth factor, steroid, and steroid antagonist regulation of cyclin gene expression associated with changes in T-47D human breast cancer cell cycle progression. Molecular and Cellular Biology 13 3577-3587.

Norris JD, Fan DJ, Wagner BL \& McDonnell DP 1996 Identification of the sequences within the human complement 3 promoter required for estrogen responsiveness provides insight into the mechanism of tamoxifen mixed agonist activity. Molecular Endocrinology 10 1605-1616.

Petz LN \& Nardulli AM 2000 Sp1 binding sites and an estrogen response element half-site are involved in regulation of the human progesterone receptor A promoter. Molecular Endocrinology 14 972-985.

Planas-Silva MD \& Weinberg RA 1997 Estrogen-dependent cyclin E-cdk2 activation through p21 redistribution. Molecular and Cellular Biology 17 4059-4069.

Porter W, Wang F, Wang W, Duan R \& Safe S 1996 Role of estrogen receptor/Sp1 complexes in estrogen-induced heat shock protein 27 gene expression. Molecular Endocrinology 10 1371-1378.

Prall OWJ, Sarcevic B, Musgrove EA, Watts CKW \& Sutherland RL 1997 Estrogen-induced activation of Cdk4 and Cdk 2 during $G_{1}-S$ phase progression is accompanied by increased cyclin D1 expression and decreased cyclindependent kinase inhibitor association with cyclin E-Cdk2. Fournal of Biological Chemistry 272 10882-10894.

Pratt MA, Satkunaratnam A \& Novosad DM 1998 Estrogen activates raf-1 kinase and induces expression of Egr-1 in MCF-7 breast cancer cells. Molecular and Cellular Biochemistry 189 119-125.

Qin C, Singh P \& Safe S 1999 Transcriptional activation of insulin-like growth factor binding protein 4 by $17 \beta$-estradiol 
in MCF-7 cells: role of estrogen receptor-Sp1 complexes. Endocrinology 140 2501-2508.

Razandi M, Pedram A, Greene GL \& Levin ER 1999 Cell membrane and nuclear estrogen receptors (ERs) originate from a single transcript: studies of ER $\alpha$ and ER $\beta$ expressed in Chinese hamster ovary cells. Molecular Endocrinology 13 307-319.

Rishi AK, Shao ZM, Baumann RG, Li XS, Sheikh MS, Kimura S, Bashirelahi N \& Fontana JA 1995 Estradiol regulation of the human retinoic acid receptor $\alpha$ gene in human breast carcinoma cells is mediated via an imperfect half-palindromic estrogen response element and Sp1 motifs. Cancer Research 55 4999-5006.

Salvatori L, Ravenna L, Felli MP, Cardillo MR, Russo MA, Frati L, Gulino A \& Petrangeli E 2000 Identification of an estrogen-mediated deoxyribonucleic acid-binding independent transactivation pathway on the epidermal growth factor receptor gene promoter. Endocrinology 141 2266-2274.

Savouret JF, Bailly A, Misrahi M, Rarch C, Redeuilh G, Chauchereau A \& Milgrom E 1991 Characterization of the hormone responsive element involved in the regulation of the progesterone receptor gene. EMBO Fournal 10 1875-1883.

Smith CL 1998 Cross-talk between peptide growth factor and estrogen receptor signaling pathways. Biology of Reproduction 58 627-632.

Sun G, Porter W \& Safe S 1998 Estrogen-induced retinoic acid receptor $\alpha 1$ gene expression: role of estrogen receptor-Sp1 complex. Molecular Endocrinology 12 882-890.

Tanaka N, Yonekura H, Yamagishi S, Fujimori H, Yamamoto Y \& Yamamoto H 2000 The receptor for advanced glycation end products is induced by the glycation products themselves and tumor necrosis factor- $\alpha$ through nuclear factor- $\kappa \mathrm{B}$, and by $17 \beta$-estradiol through $\mathrm{Sp}-1$ in human vascular endothelial cells. Fournal of Biological Chemistry 275 25781-25790.

Vignon F, Bouton M-M \& Rochefort H 1987 Antiestrogens inhibit the mitogenic effect of growth factors on breast cancer cells in the total absence of estrogens. Biochemical and Biophysical Research Communications 146 1502-1508.

Wakeling AE, Newboult E \& Peters SW 1989 Effects of antioestrogens on the proliferation of MCF-7 human breast cancer cells. Fournal of Molecular Endocrinology 2 225-234.

Wang F, Porter W, Xing W, Archer TK \& Safe S 1997 Identification of a functional imperfect estrogen responsive element in the $5^{\prime}$-promoter region of the human cathepsin D gene. Biochemistry 36 7793-7801.

Wang F, Hoivik D, Pollenz R \& Safe S 1998 Functional and physical interactions between the estrogen receptor-Sp1 and the nuclear aryl hydrocarbon receptor complexes. Nucleic Acids Research 26 3044-3052.

Wang F, Duan R, Chirgwin J \& Safe S 2000 Transcriptional activation of cathepsin D gene expression by growth factors. Fournal of Molecular Endocrinology 24 193-202.

Wang W, Smith R \& Safe S 1998 Aryl hydrocarbon receptormediated antiestrogenicity in MCF-7 cells: modulation of hormone-induced cell cycle enzymes. Archives of Biochemistry and Biophysics 356 239-248.

Wang W, Dong L, Saville B \& Safe S 1999 Transcriptional activation of E2F1 gene expression by $17 \beta$-estradiol in MCF-7 cells is regulated by NF-Y-Sp1/estrogen receptor interactions. Molecular Endocrinology 13 1373-1387.

Weber JD, Hu W, Jefcoat SCJ, Raben DM \& Baldassare JJ 1997 Ras-stimulated extracellular signal-related kinase 1 and RhoA activities coordinate platelet-derived growth factorinduced G1 progression through the independent regulation of cyclin D1 and p $27^{\mathrm{KIP} 1}$. Fournal of Biological Chemistry 272 32966-32971.

Weigel NL \& Zhang Y 1998 Ligand-independent activation of steroid hormone receptors. Fournal of Molecular Medicine 76 469-479.

Westley BR \& May FEB 1994 Role of insulin-like growth factors in steroid-modulated proliferation. Fournal of Steroid Biochemistry and Molecular Biology 51 1-9.

Wilding G, Lippman ME \& Gelmann EP 1988 Effects of steroid hormones and peptide growth factors on protooncogene c-fos expression in human breast cancer cells. Cancer Research 48 802-805.

Xie W, Duan R \& Safe S 1999 Estrogen induces adenosine deaminase gene expression in MCF-7 human breast cancer cells: role of estrogen receptor-Sp1 interactions. Endocrinology 140 219-227.

Xie W, Duan R, Chen I, Samudio I \& Safe S 2000 Transcriptional activation of thymidylate synthase by $17 \beta$-estradiol in MCF-7 human breast cancer cells. Endocrinology 141 2439-2449.

Zacharewski TR, Bondy KL, McDonell P \& Wu ZF 1994 Antiestrogenic effects of 2,3,7,8-tetrachlorodibenzo- $p$-dioxin on $17 \beta$-estradiol-induced $\mathrm{pS} 2$ expression. Cancer Research 54 2707-2713.

Zimmermann S \& Moelling K 1999 Phosphorylation and regulation of Raf by Akt (protein kinase B). Science 286 1741-1744.

RECEIVED 10 November 2000

ACCEPTED 19 February 2001 